\title{
Morphometric study of the small intestinal mucosa in young, adult, and old rats submitted to protein deficiency and rehabilitation
}

\author{
MARIA A M RODRIGUES, J L V DE CAMARGO, K I R COELHO, \\ M R G MONTENEGRO, A Y O ANGELELI, AND R C BURINI
}

From Departments of Pathology and Medicine (Nutrition Division). Faculdade de Medicina de Botucatu, São Paulo, Brazil

SUMMARY Linear and stereological morphometric methods were applied to the jejunal and ileal mucosa of young, adult, and old male Wistar rats submitted to protein deficiency and rehabilitation. The animals were fed ad libitum a $2 \%$ casein diet during 42 days and then received a $20 \%$ casein diet for 30 days. Food intake, body weights, and plasma protein concentrations were recorded. In the young protein deficient rats values of mucosal height, surface area, and volume of the lamina propria were significantly lower than those of their age controls in both jejunum and ileum. In adults the differences were less marked and in the old rats all parameters were found to be unaltered by the protein deficient diet. The surface-to-volume ratio showed no significant differences between control and protein deficient in all three age groups, meaning that villus pattern did not change with protein deficiency. On rehabilitation, a striking difference between jejunum and ileum was observed in the young rats; all parameters returned to control levels in the jejunum, while they remained lower than those of their controls in the ileum.

The morphological alterations of the small intestinal mucosa have been extensively studied in human malnutrition. ${ }^{1-5}$ Animal models have shown a reduction in mucosal height with no apparent changes on villus pattern ${ }^{6-9}$ and it has been said that the small intestinal mucosa does not seem to be a prime target organ of protein deprivation. ${ }^{8}$ These experimental studies, however, were based on linear measurements of mucosal thickness and on simple visual assessment of the histological appearances of the villus pattern. None has carried out a quantitative examination of tissue components or has used objective methods ${ }^{10-15}$ in the evaluation of changes in villus pattern. In addition, few investigations ${ }^{7} 8$ have considered more than one site of the intestine or have assessed the influences of age and rehabilitation on the morphology of the mucosa. ${ }^{16}$

With this in mind we decided to quantify experimentally the effects of protein deficiency on villus pattern and tissue components of the jejunal

Address for correspondence: Dr Maria Ap M Rodrigues, Departmento de Patologia, Faculdade de Medicina, UNESP, 18600 Botucatu, São Paulo, Brazil.

Received for publication 15 October 1984 and ileal mucosa as well as to assess whether the quantitative changes, if any, are modified by the age of the animals or by rehabilitation.

\section{Methods}

RATS

Seventy five male Wistar rats, 25 young ( 30 day old, mean weight $60 \mathrm{~g}$ ), 25 adult (60 day old, mean weight $200 \mathrm{~g}$ ) and 25 old (more than one year old, weighing about $450 \mathrm{~g}$ ) were studied. They were placed in individual wire cages in a temperature controlled room $\left(21-25^{\circ} \mathrm{C}\right)$ with a 12 hour, light period. All rats were initially fed on a $20 \%$ casein diet (control diet) ad libitum for five to 10 days (adaptation period). At this moment (M1) five animals of each age group were killed as initial controls. The remaining were assigned to receive a $2 \%$ isoenergetic casein diet $^{17}$ (10 rats/diet group) or a $20 \%$ casein diet (age control group) for 42 days. At the end of this period (M2) five protein deficient and five control rats of each age group were killed and the remaining allowed access to the control diet during 30 days (rehabilitation period: M3). Food and tap water were provided ad libitum throughout 
the experiment. All animals were weighed weekly and their dietary consumption recorded daily. They were killed by a sharp blow on the head and blood was collected for plasma protein determination. ${ }^{18}$

Small segments $(1.5-2.5 \mathrm{~cm})$ of all killed animals were quickly obtained from proximal jejunum, just beyond the ligament of Treitz and from distal ileum, $2-3 \mathrm{~cm}$ proximal to the ileocaecal valve. These segments were placed serosal side down on a piece of cardboard, immersed in Bouin's fixative for 72 hours and embedded in paraffin; blocks were sectioned on the same microtome, at the same setting of $4 \mu \mathrm{m}$ and stained by haematoxylin and eosin for qualitative examination of the mucosa and by Periodic Acid-Schiff reaction for measurements. All samples of jejunum and ileum were evaluated blindly by one of the authors (MAMR).

\section{MEASUREMENTS}

In perpendicular oriented histological sections, mucosal height was assumed as the distance from the apex of the villus to the base of the crypt. Using a calibrated micrometric eye piece 20 measurements were done in each segment of each rat at $40 \times$ magnification. Measurements of the mucosal surface area, volume of the lamina propria and the relationship between these two parameters (surface to volume ratio) were performed according to Dunnill and Whitehead ${ }^{11}$ slightly modified. Briefly, the sections were projected with a Zeiss projector on a template containing 15 equally long lines $\left(1=1.37 \times 10^{-2} \mathrm{~cm}\right)$. The magnification and the distance between the projector and the template were kept constant throughout the investigation. The number of cutting points between the mucosal surface and the lines was recorded. The number of endpoints of the lines hitting the tissue between the mucosal cells and the muscularis mucosae was also recorded. The mean number of cuts (c) per microscopic field is proportional to the mucosal surface area; the mean number of hits (h) reflects the volume of the lamina propria and the relationship $\mathrm{c} / \mathrm{lxh}$ is an expression of the surface/volume ratio, which is an index of the complexity of the villus pattern. ${ }^{11}$ The minimal necessary number of fields to be counted was calculated by using the progressive mean method, ${ }^{19}$ which showed that the minimal sample size was 15 fields per section; 20 fields were counted in each section from each rat.

Profile analysis ${ }^{20}$ was used for statistical assessment of the results. This analysis was carried out with all nutritional and morphometrical data gathered at the three experimental moments (M1, $\mathrm{M} 2$ and M3). We will discuss only data related to the effects of protein deficiency (M2) and rehabilitation (M3).

\section{Results}

\section{NUTRITIONAL DATA}

The protein deficient rats exhibited loss of hair especially around the neck and over the perigenital areas. They also became apathetic and irritable when handled. These abnormalities were most marked in the young rats and gradually disappeared on rehabilitation. Only one young protein deficient rat developed diarrhoea three days before being killed. There were no deaths and oedema was not observed in any of the animals. Mean food intake per unit of body weight in young and adult protein deficient animals was greater than those of their respective controls; deficient old rats did not show any quantitative alteration of daily food intake.

The protein deficient rats of the three age groups showed weight loss, so that their final mean body weights were significantly lower $(p<0 \cdot 0001)$ than those of their age controls (Fig. 1). On rehabilitation, the body weight of the three age protein deficient rats rose significantly $(p<0 \cdot 0001)$ when compared with the values registered at M2. These values were significantly lower than those of their respective controls for the young $(p<0.0001)$ and adult $(\mathrm{p}<0.002)$ animals. Young and adult control animals gained body weight throughout the experiment (Fig. 1).

Plasma protein concentrations were significantly lower in the young $(p<0 \cdot 0001)$ and adult $(p<0.0009)$ protein deficient rats. On rehabilitation, these values rose significantly in both groups, but in the young animals they remained lower $(p<0.0003)$ than those of the controls. There were no significant changes on plasma protein concentrations in the old rats during protein deficiency or after rehabilitation (Fig. 1).

\section{QUALITATIVE STUDY OF THE SMALL INTESTINE}

Visual inspection showed diminished circumferences and thinner walls, especially in the young protein deficient rats. The mucosae looked pale with less prominent granularity than that seen in the control rats. Microscopically, the villus pattern was maintained and there were no distinguishable differences on the histological findings neither among protein deficient, rehabilitated and control rats, nor among the three age groups. The only abnormality found was in the ileum of the young protein deficient rat which developed diarrhoea. The ileal mucosa of this animal showed patches of low flattened villi with inversion of the villus-crypt ratio. The epithelial cells covering these atrophic villi were cuboidal but no inflammatory changes were seen in the lamina propria. 


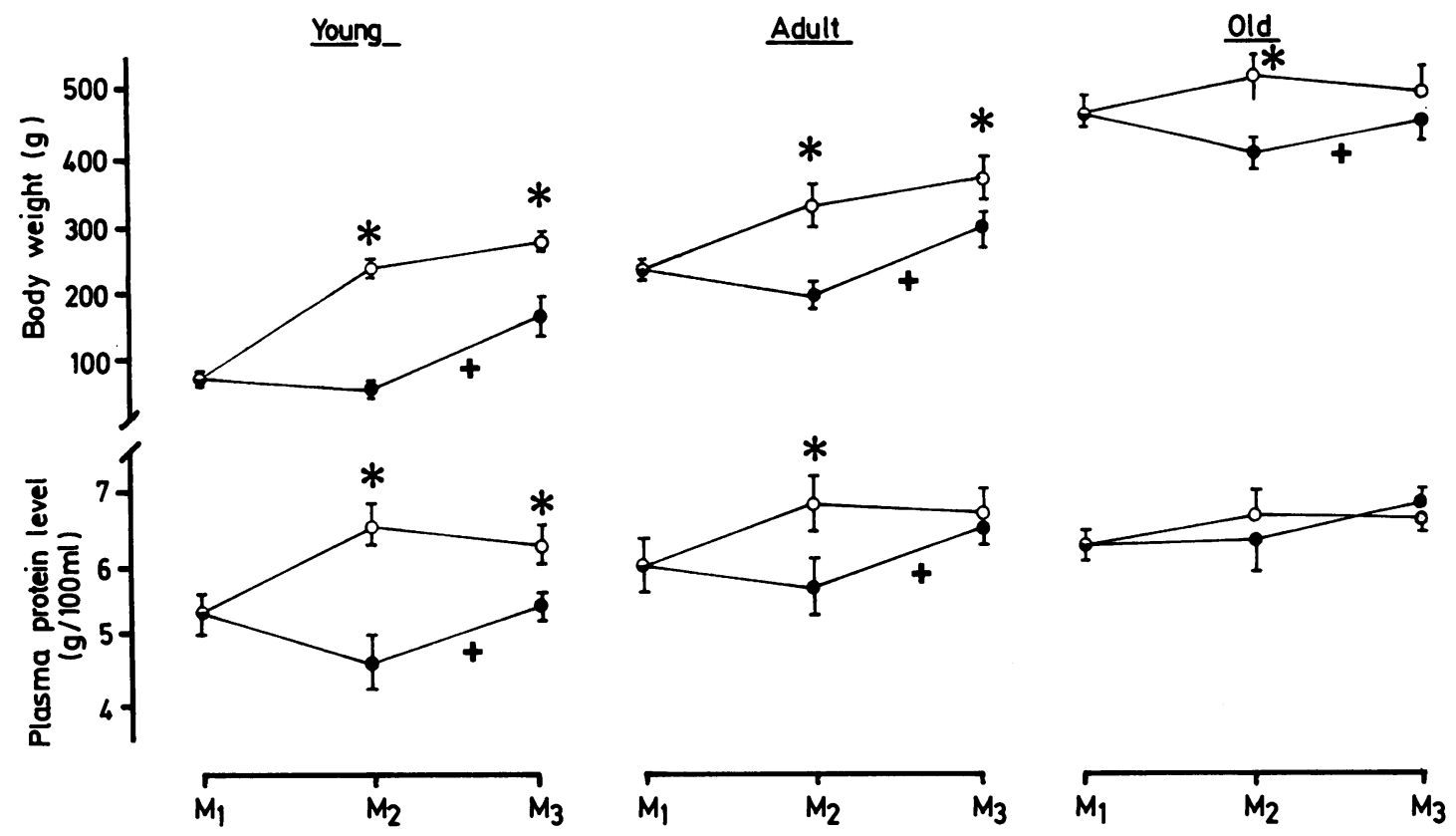

Fig. 1 Body weights $(\mathrm{g})$ and plasma protein concentration $(\mathrm{g} / 100 \mathrm{ml})$ of the three age groups at the starting moment (M1), on protein deficiency (M2) and after rehabilitation (M3). $\bigcirc$ Protein deficient or rehabilitated; $\bigcirc$ age control. Points represent means $\pm S D .{ }^{*} p<0.05(0 \times 0) ;+p<0.05(M 2 \times M 3)$.

MORPHOMETRIC ANALYSIS

Values of mucosal height, surface area, and volume of the lamina propria were significantly lower in the young protein deficient rats (M2) than those of the age controls, both in jejunum $(\mathrm{p}<0.0001)$ and ileum $(\mathrm{p}<0.0009)$ (Figs. 2 and 3). On rehabilitation (M3), the values of all these variables increased significantly $(\mathrm{p}<0.04)$ in the jejunum and were similar to those of their controls (Fig. 2). In the ileum, mucosal height returned to that of the control values; the surface area rose slightly but did not reach the values of the controls; the volume of the lamina propria also rose slightly, but was not significantly different from those of the protein deficient animals (Fig. 3).

In the adult rats, the variables measured in the jejunum and ileum were also lower in protein deficient animals but the differences were less marked (Figs. 2 and 3). In the jejunum, the mucosal height and volume of the lamina propria of the undernourished animals were significantly lower $(p<0.02)$ than those of the controls. In the ileum, the differences were significant for mucosal height $(\mathrm{p}<0.02)$ and surface area $(\mathrm{p}<0.04)$. On rehabilitation, the values of these parameters increased up to the levels of the controls in both jejunum and ileum (Figs. 2 and 3).
Old rats, did not show significant differences between age controls and undernourished or rehabilitated animals for all parameters measured both in jejunum and ileum (Figs. 2 and 3).

Neither protein deficiency nor rehabilitation affected the surface to volume ratio of the jejunum and ileum, in all the three age groups (Figs. 2 and 3 ).

\section{Discussion}

Our results show that the histology of the small intestinal mucosa and the linear measurements of mucosal height are in agreement with previous studies on protein deficiency. ${ }^{6-9}$ There was reduction in mucosal height, surface area and volume of the lamina propria, in both jejunum and ileum, especially in the young protein deficient rats. Hill et $a l^{\prime}$ found that villi of young protein deficient rats were thinner than those of controls; we also observed narrowed villi in the jejunal mucosa of adult rats on protein free diet. ${ }^{9}$ The thinning of the mucosa suggests that protein deficiency affects not only the epithelial cell compartment ${ }^{21}$ but the mucosa as a whole.

Because there was concommitant decrease of mucosal surface area and volume of lamina propria, surface to volume ratios were similar in protein 

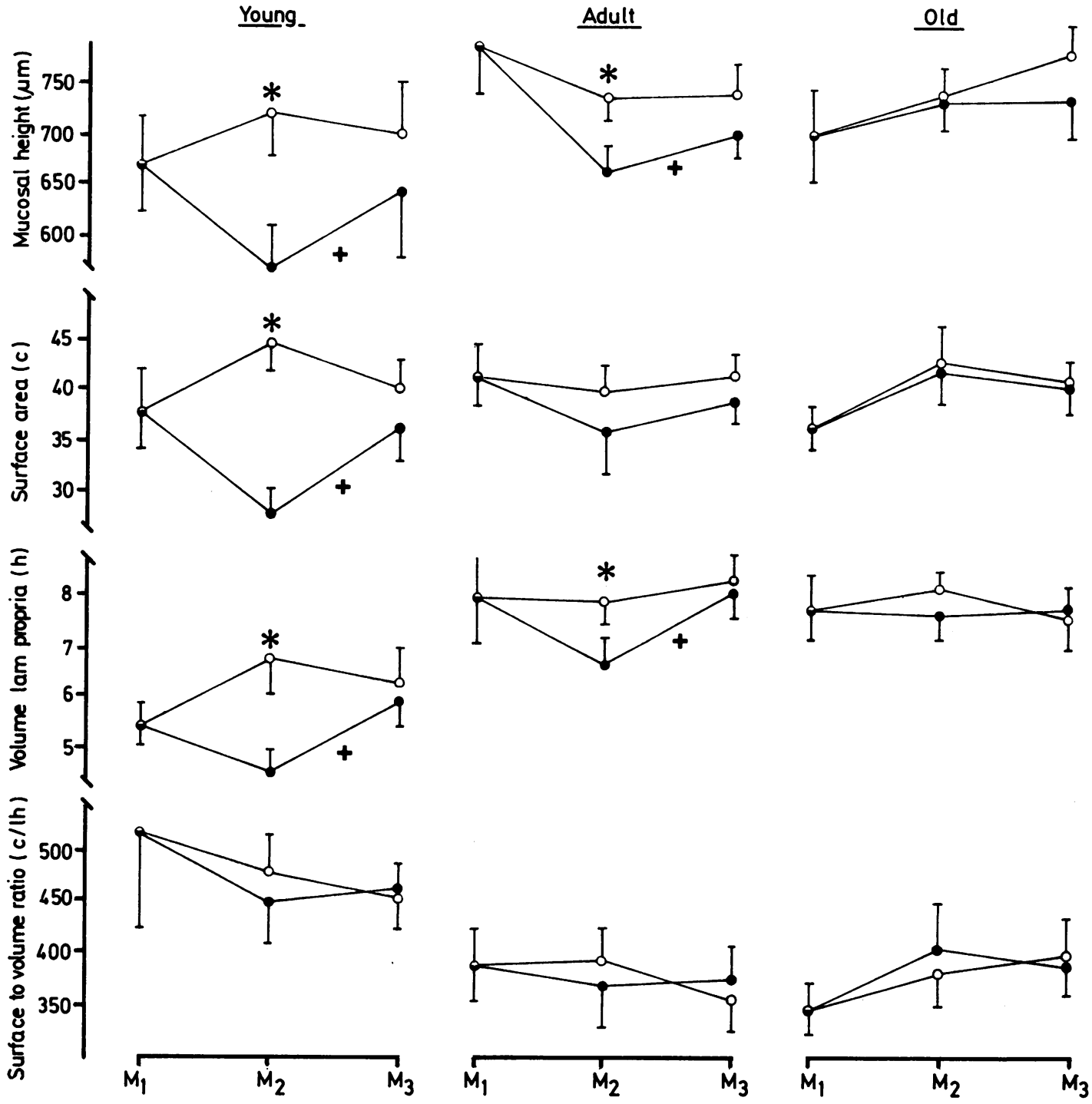

Fig. 2 Morphometric results of the jejunal mucosa in the three age groups. Abscissa: experimental moments, M1 starting, $M 2$ end of protein deficiency, $M 3$ end of rehabilitation. Ordinate (from above downwards): mucosal height ( $\mu \mathrm{m})$; surface area $(c)$, volume of lamina propria $(h)$ and surface to volume ratio $(c / l x h)$. Protein deficient or rehabilitated; $\bigcirc$ age control. Points represent means $\pm S D .{ }^{*} p<0.05(0 \times 0) ;+p<0.05(M 2 \times M 3)$.

deficient rats and controls or, in other words, villus pattern was not affected by protein deficiency. The maintenance of villus pattern in spite of a reduction in tissue components may reflect an adaptation of the mucosa to the low protein diet.

On rehabilitation all morphometric parameters returned to control values except for the ileum of young rats. The difference between jejunum and ileum might be related to their location in the gut; the proximal segment having the first opportunity to absorb aminoacids would restore its integrity faster than the distal. ${ }^{723}$ In fact, in the ileum, the surface area and volume of the lamina propria remained lower than those of controls, although mucosal height returned to normal. The apparent disagreement between data on these parameters could be 

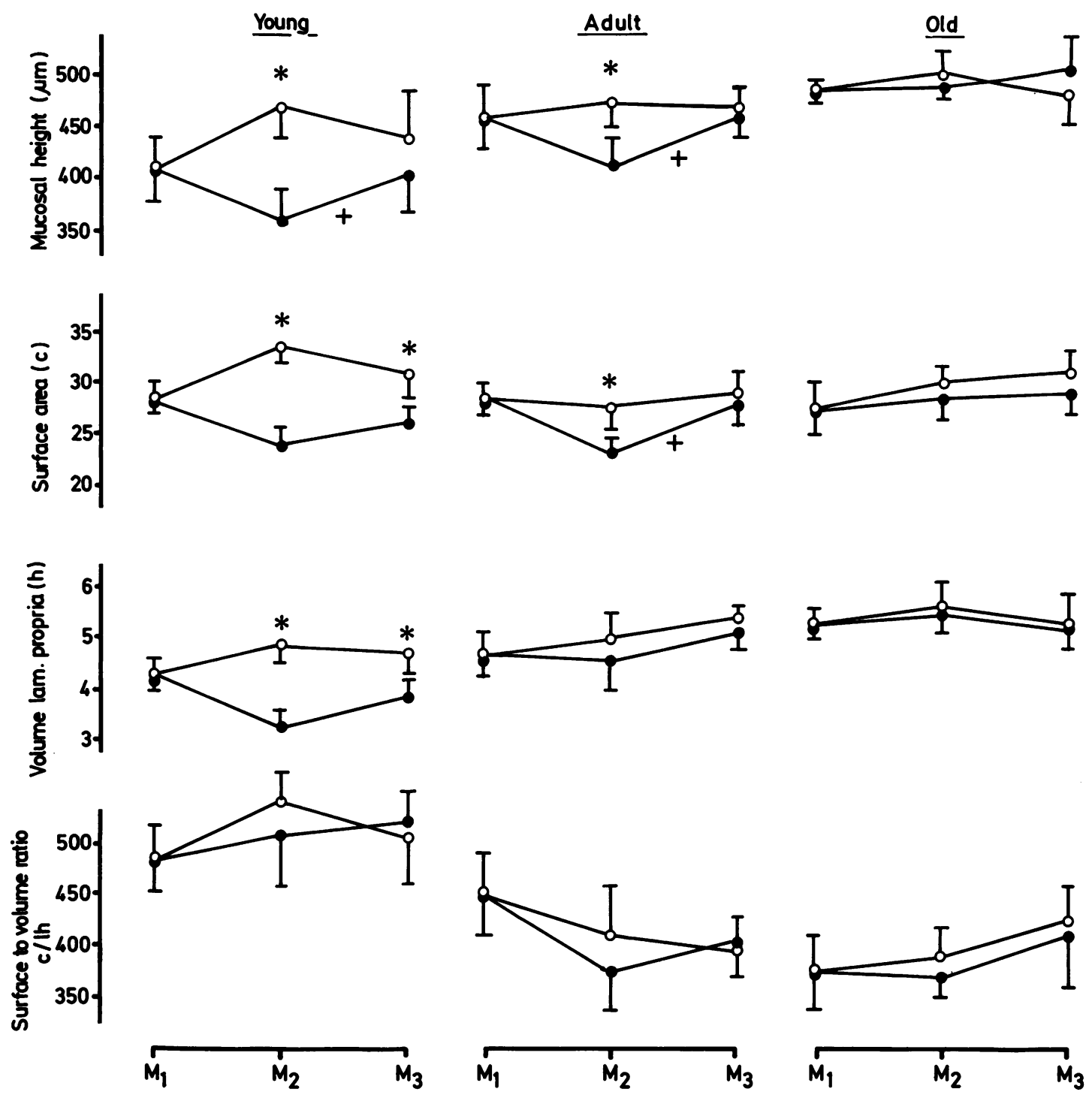

Fig. 3 Morphometric results of the ileal mucosa in the three age groups. Abscissa: experimental moments, M1 starting, M2 end of protein deficiency, $M 3$ end of rehabilitation. Ordinate (from above downwards): mucosa height ( $\mu \mathrm{m})$, surface area (c), volume of lamina propria (h) and surface to volume ratio (c/lxh). Protein deficient or rehabilitated; $\bigcirc$ age control. Points represent means $\pm S D .{ }^{*} p<0.05(0 \times 0) ;+p<0.05(M 2 \times M 3)$.

because of the different approaches used in examining the mucosa (linear $v s$ stereological methods). Even taking account of the limitations of the methods, stereology seems to be more accurate in distinguishing minor changes of the mucosa. ${ }^{11}$ Furthermore the results from surface area and volume of the lamina propria of the ileum correlate well with the nutritional parameters obtained for the young rats: their body weights and plasma protein concentrations did not reach those of the controls after rehabilitation.

The only abnormality of the villus pattern found was a patchy flattening of the ileal mucosa in the young protein deficient rat with diarrhoea before being killed. Association between diarrhoea and altered mucosa is known in the human protein 
deficiency syndrome $\mathrm{e}^{1-5}$ but is an uncommon finding in experimental studies of protein deficiency. ${ }^{84}$ The human syndrome is often complicated by infections, infestations and other nutritional deficiences $^{25}$ which may play a role in the alterations of the mucosa.

In our model the small intestinal mucosa, although retaining its villus pattern, was affected by protein deprivation and was capable of recovery with protein deficiency reversal. The young protein deficient were more severely affected than the adult and old age rats. This is in close agreement with the nutritional data: both morphometric and nutritional results emphasise the greater susceptibility of the growing organisms to the deleterious effects of protein deficiency.

\section{References}

1 Stanfield JP, Hutt, MSR, Tunnicliffe R. Intestinal biopsy in kwashiorkor. Lancet 1965; 11: 519-23.

2 Burman D. The jejunal mucosa in kwashiorkor. Arch Dis Child 1965, 40: 526-31.

3 Barbezat GO, Bowie MD, Kaschula ROC, Hansen JDL. Studies on the small intestinal mucosa of children with protein-calorie malnutrition. $S$ Afr Med J 1967; 41: 1031-6.

4 Brunser O, Reid A, Mönckeberg F, Maccioni A, Contreras I. Jejunal mucosa in infant malnutrition. Am J Clin Nutr 1968; 21: 976-83.

5 Tandon BN, Magotra ML, Saraya AK, Ramalingaswami V. Small intestine in protein malnutrition. $\mathrm{Am}$ J Clin Nutr 1968; 21: 813-9.

6 Deo MG, Sood SK, Ramalingaswami V. Experimental protein deficiency. Arch Pathol 1965; 80: 14-23.

7 Hill Jr RB, Prosper J, Hirschfield JS, Kern Jr F. Protein starvation and the small intestine. I. The growth and morphology of the small intestine in weanling rats. Exp Mol Pathol 1968; 8: 66-74.

8 Madi K, Jervis HR, Anderson PR, Zimmerman MR. A protein-deficient diet. Effect on the liver, pancreas, stomach, and small intestine of the rat. Arch Pathol 1970; 89: 38-52.

9 Maffei HVL, Rodrigues MAM, Carmago JLV, Cam- pana AO. Intraepithelial lymphocytes in the jejunal mucosa of malnourished rats. Gut 1980; 21: 32-6.

10 Madanagopalan N, Shiner M, Rowe B. Measurements of small intestinal mucosa obtained by peroral biopsy. Am J Med 1965; 38: 42-53.

11 Dunnill MS, Whitehead R. A method for the quantitation of small intestinal biopsy specimens. J Clin Pathol 1972; 25: 243-6.

12 Chapman BL, Henry K, Paice F, Stewart JS, Coghill NF. A new technique for examining intestinal biopsies. Gut 1973; 6: 905-9.

13 Meinhard EA, Wadbrook DG, Risdon RA. Computer card morphometry of jejunal biopsies in childhood coeliac disease. J Clin Pathol 1975; 28: 85-93.

14 Guix M, Skinner JM, Whitehead R. Measuring intraepithelial lymphocytes, surface area, and volume of lamina propria in the jejunal mucosa of coeliac patients. Gut 1979; 20: 275-8.

15 Fallstrom SP, Kristiansson B, Ryd W. Histological studies of small-intestinal biopsies from infants with low rate of weight gain. Acta Path Microbiol Scand Sect A 1981; 89: 431-8.

16 Cook GC and Lee FD. The jejunum after kwashiorkor. Lancet 1966; 2: 1263-7.

17 Angeleli AYO, Burini RC, Campana AO. Body collagen nitrogen in protein-deficient adult rats. $J$ Nutr 1978; 108: 1147-53.

18 Henry RJ. Proteins. In: Clinical chemistry: principles and technics. New York: Harper and Row, 1964: $182-4$.

19 Williams MA. Quantitative methods in biology. NorthHolland Publishing Company: Amsterdam, 1977: 36-8.

20 Morrison DF. Multivariate statistical methods. New York: McGraw Hill, 1967.

21 Deo MG, Ramalingaswami V. Reaction of the small intestine to induced protein malnutrition in rhesus monkeys - A study of cell population kinetics in the jejunum. Gastroenterology 1965; 49: 150-7.

22 Hopper AF, Wannemacher Jr RW, McGovern PA. Cell population changes in the intestinal epithelium of the rat following starvation and protein-depletion. Proc Soc Exp Biol Med 1968; 128: 695-8.

23 Hirschfield JS, Kern Jr F. Protein starvation and the small intestine. III. Incorporation of orally and intraperitoneally administered leucine $4,5-{ }^{3} \mathrm{H}$ into intestinal mucosal protein of protein-deprived rats. J Clin Invest 1969; 48: 1224-9.

24 Takano J. Intestinal changes in protein-deficient rats. Expl Mol Pathol 1964; 3: 224-31.

25 Scrimshaw NS. Ecological factors in nutritional disease. Am J Clin Nutr 1964; 14: 112-22. 